\title{
APHIDIDAE OF PERSIA.
}

\author{
By F. V. Theobald.
}

Aphis buxtoni, sp. nov. (fig. 1).

Alate viviparous female.

Head and thorax dark; abdomen pale, apparently pale green, with dark lateral spots. Antennae, cauda and cornicles dark. Legs with mid and hind femora dark, front pair paler; apices of tibiae and the tarsi dark. Antennae shorter than body, rather thick; basal segment larger and paler than second; third much longer than fourth and about as long as the sixth, with 18-20 small round pale sensoria over its whole length; fourth segment very slightly longer than fifth, with 5-8 sensoria; fifth with 4-7 sensoria of unequal size, exclusive of the usual subapical one; sixth with the rather thick basal area less than one-third the length of flagellum, in some however almost half its length; all the segments from the third imbricated. Eyes

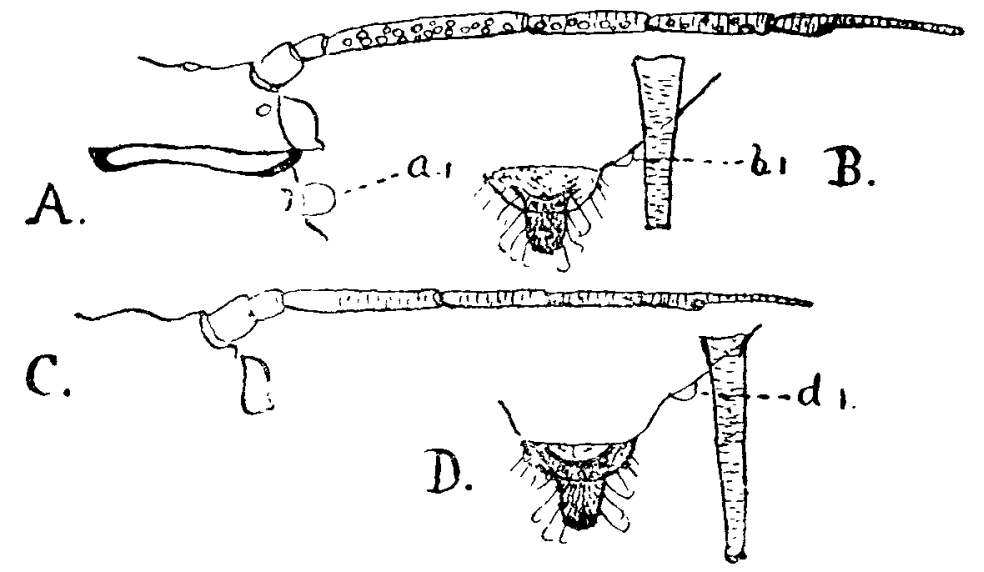

Fig. 1. Aphis buxtoni,sp.n.: A, B, alate $\&$; $a_{1}$, lateral bladder-like papilla; $b_{1}$, lateral papilla; $\mathrm{C}, \mathrm{D}$, apterous $ᄋ$; $d_{1}$, lateral papilla.

large. Proboscis reaching to the third coxae. A large pale bladder-like papilla on each side of pronotum and five pairs of pale rounded papillae on sides of abdomen. Cornicles about as long and as thick as third antennal segment, cylindrical, markedly imbricated, not reaching to the level of the cauda. Cauda bluntly pointed, about half the length of the cornicles, spinose ; with numerous fine hairs, curved apically. Anal plate spinose, with fine pale hairs. Tibiae with numerous fine, pale, short hairs. Wings with normal venation; veins and stigma brown, the veins very faintly and narrowly clouded on each side. Length, $2-2 \cdot 2 \mathrm{~mm}$.

Apterous viviparous female.

Pallid, with dark head, cornicles, cauda and anal plate, also dark antennae and mid and hind legs, the fore pair paler. Antennae shorter than body, rather thick; basal segment larger than second, both very dark ; third paler at base, longer than fourth and about same length as sixth ; fourth a little longer than fifth, the latter with the usual sub-apical sensorium; sixth with basal area nearly half the length of 
flagellum; segments 3-6 imbricated. Eyes dark, of moderate size. Proboscis reaching to the second coxae. Cornicles cylindrical, longer than third antennal segment, imbricated. Cauda blunt and rather short, not half the length of the cornicles, spinose, with numerous pale hairs ; broader than cornicles ; the hairs curved apically. Anal plate spinose, with long pale hairs. The rather thick set legs have the coxae and trochanters darker than the rest of the legs ; a few short hairs on the femora, many on the tibiae. Length, 2 to $2.5 \mathrm{~mm}$.

Food-plant: Umbelliferae.

Persia : Enzeli, Caspian Coast, 6.vi.1919 (P. A. Buxton).

Types in the British Museum.

Described from a single perfect alate female and several apterae. One of the latter shows the cornicles not reaching the cauda, others passing it. It is a very marked species, the black cornicles, cauda, etc., showing up prominently against the pale body. The antennae are short, as in the genus Cavariella and the cauda is markedly spinose. I can see no trace in the mounted apterae of any lateral pronotal or abdominal papillae, as seen in the alate female. The larval stages are more uniform in colour, but in succeeding instars the blackness of the cornicles, etc., gradually becomes more pronounced.

This species was found in association with an ant that has been identified by Mr. W. C. Crawley as Lasius emarginatus, Latr., var. nigro-emarginatus, Forel.

Myzus mespiliella, sp. nov. (fig. 2).

Apterous viviparous female.

Green or yellowish green; antennae of same colour as body, dusky at apex of fifth segment, the sixth dusky, with a more or less darkened area at the junction of basal portion and flagellum. Eyes deep reddish-black. Proboscis of same colour as body, dark at apex. Legs same colour as body, apex of tibiae and tarsi dusky. Cornicles and cauda of same colour as body; in some the former seem a little darker. Anal plate darker than cauda.

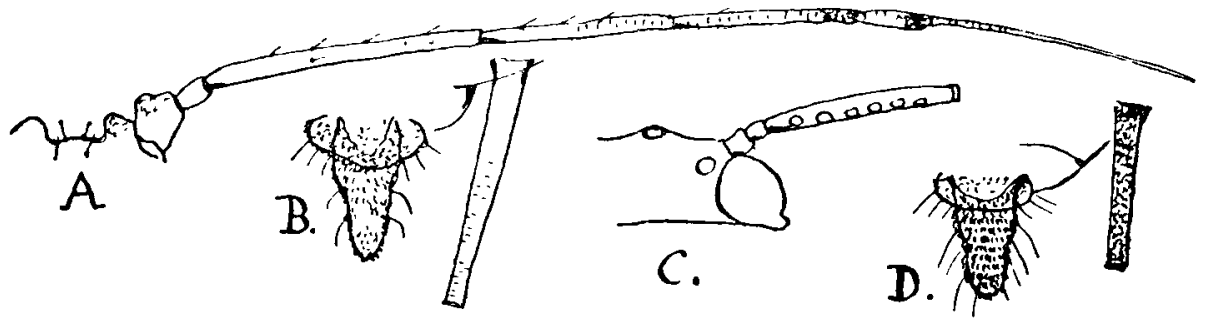

Fig. 2. Myzus mespiliella, sp. n. : A, B, apterous 9 ; C, D, alate ․

Antennae longer than body; basal segment larger than second ; third segment longer than fourth, but not quite so long. as the sixth; fourth a little longer than fifth; the sixth about as long as $4+5$, with moderately long flagellum; a few short hairs on third and fourth. Proboscis rather long, reaching to or just beyond the third coxae. Cornicles slightly longer than fourth antennal segment, cylindrical, slightly broadening at the base, markedly imbricated. Cauda reaching not quite to the level of the cornicles, less than half their length, narrowly triangulate or pointed, spinose, with two pairs of lateral hairs. Anal plate spinose, with several long hairs. Tibiae with numerous small hairs, becoming longer near apex. The 
vertex shows two short and two longer slightly capitate hairs. A few short blunt lateral abdominal processes. Length, $1 \cdot 5-1 \cdot 8 \mathrm{~mm}$.

Alate viviparous female.

Only imperfect specimens sent. Apparently dark and of reddish hue with dark head, thorax, cornicles and cauda; legs paler, with dark apices to tibiae and dark tarsi ; two basal segments of antennae dark, third pale. The abdomen has dark lateral and dorsal spots and the proboscis is pale towards the tip, but extreme apex dark. The basal segment of antennae larger than second ; the third with 6-7 large round sensoria in a line. Eyes large and deep reddish-black. The black cornicles are cylindrical, shorter, but a little thicker than third antennal segment, slightly expanding basally and not quite reaching the level of the cauda, markedly imbricated. Cauda black, more than half the length of the cornicles, more or less constricted near the middle, spinose, with long. fine hairs; blunt apically. Anal plate black, with long pale hairs. Wings large, venation normal. The abdomen shows four small dark blunt lateral processes before the cornicles and one between the cornicles and cauda. Length, $1 \cdot 8-2 \mathrm{~mm}$.

Food-plant: Medlar (Mespilus).

N. W. Persia : Enzeli, 29.iv.1919 (P. A. Buxton).

Types in the British Museum.

Described from several perfect apterous females, but both alatae damaged, neither showing complete antennae. The sensoria on the third segment are marked. The only other Mespilus species is Van der Goot's Mysus mespili, which is very distinct. The vertex and lobes of the apterae and the basal segment of the antennae approach to some extent those of the genus Phorodon, but in the alate stage it is a distinct Myzus. It was found on the young twigs of the medlars, not doing much harm. Ants were found in attendance.

Aphis punicae, Passerini (fig. 3).

A. punicae, Pass., Aphid. Italicae, pp. 32 et 42, n. 26 (1863).

Alate viviparous female.

Antennae shorter than body; two basal segments dark and a dark area at apex of fifth and around the sensoria on sixth, or all dark except base of third segment;

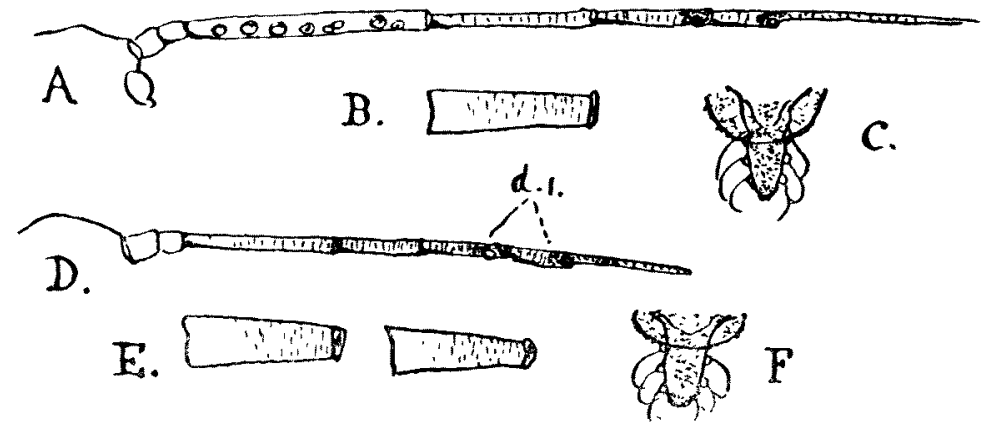

Fig. 3. Aphis punicae, Pass. : $\mathrm{A}, \mathrm{B}, \mathrm{C}$, alate 9 ;

$\mathrm{D}, \mathrm{F}, \mathrm{F}$, apterous $q$; $d_{1}^{\overline{4}}$, dark areas on antennae.

basal segment wider but no longer than second ; third nearly as long as the sixth, with 6-8 sensoria spread over its whole length, two frequently smaller than the others; fourth segment longer than fifth, the latter with the usual subapical sensorium; the sixth about as long as $4+5$; fourth to sixth imbricated. Cornicles 
dark, about as long as fourth antennal segment and thicker, cylindrical, imbricated, not reaching to the tip of cauda. Cauda pale, shorter than the cornicles, with three pairs of lateral hairs, curved apically and arising from prominent tubercles. Anal plate darker than cauda. Femora of mid and hind legs dark, except just at base ; front pair paler; apices of tibiae and the tarsi dark. Wings normal. Length, 1-1.5 mm.

Apterous viviparous female.

Antennae shorter than body, pallid, except for a small dark area at apex of fifth segment and one around sensoria on sixth; basal segment wider but scarcely longer than second ; third a little shorter than sixth, but longer than fourth; fourth and fifth about equal; sixth with flagellum about twice as long as basal area. Cornicles about as long as third antennal segment, broadening basally, pale, dark at apex, not reaching as far as cauda. Cauda pale, with three hairs on each side, curved at their tips and arising from marked tubercles; not quite as long as cornicles. Anal plate dark. Marked pronotal lateral tubercles and one each side of body before the hind legs. Apices of tibiae and the tarsi dark. Proboscis not reaching to third coxae. Length, $1-1.5 \mathrm{~mm}$.

Food-plant: Wild Pomegranate.

N.W. Persia : Tula Road, Talish District, S.W. Coast of Caspian, 9. vii. and 5. viii. 1919 (P. A. Buxton). Italy (Passerini and Theobald).

Apparently the apterae only were described by Passerini. The alatae seem to vary in the colour of the antennae in the mounted specimens, some are pale with two dark areas, others all dark except the base of the third segment. The specimens taken by Mr. Buxton were on the twigs, attended by ants (Cremastogaster scutellaris schmidti, Mayr, and Tapinoma erraticum nigerrimum, Nyl.). Passerini records it from Punica granatum and $P$. sylvestris. The Aphis punicellae I described from Egypt on $P$. granatum (Bull. Ent. Res. vi, p. 125) is quite a distinct species.

Lachnus pyri, Buckton (fig. 4).

L. pyri, Buckt., Indian Museum Notes, iv, p. 271, pl. xvi (1899).

Taken on pears at Karmanshah, W. Persia (4. xii. 18) by Mr. P. A. Buxton.

This species was described by Buckton (with notes by E. E. Green) from pears in Ceylon. The Persian specimens agree with the Pear Lachnid I have from Ceylon and answer generally to Buckton's short description. I append some characters of the antennae, etc.

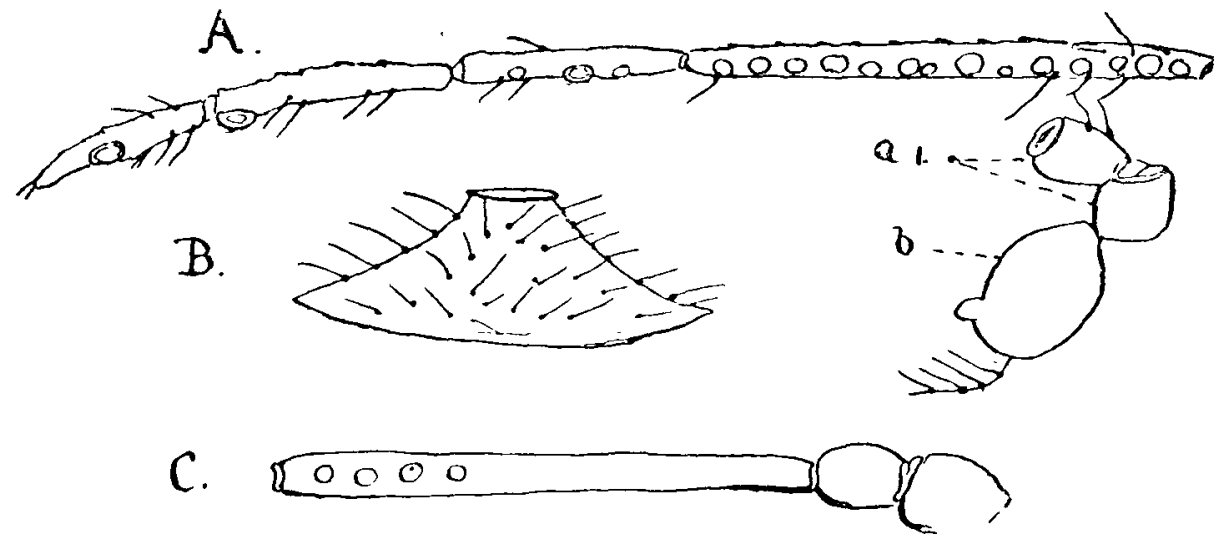

Fig. 4. Lachnus pyri, Buckt. : A, antenna of alate $q$; $a$, basal segments; $b$, eye; $\mathrm{B}$, cornicle; C, 1 st to 3 rd antennal segments of apterous $q$. 
Alate viviparous female.

Antennae of six segments; first two large and dirk, third the longest, with 13-15 round sensoria of unequal size and a few hairs ; fourth about as long as fifth, with 3 sensoria ; fifth longer than sixth, with one large subapical sensorium; sixth with 'nail' shorter than basal area and a large sensorium at its base, a few moderately long hairs. Eyes large. Cornicles dark, of normal form, hairy.

Apterous viriparous female.

Basal segments of antennae large and dark; third segment with $3-4$ uniform round sensoria situated near apex. Cornicles as in alate $q$. A marked median abdominal tubercle.

The specimens sent by Mr. Buxton were all very much damaged. Another Lachnid (Nippolachnus piri, Matsumura) occurs on Pirus sinensis in Japan, but is very distinct (vide, "A list of the Aphididae of Japan, with descriptions of New Species," Journal of the College of Agriculture, Tohoku Imperial University, vii. pt. 6, p. 382, Jụly 1917). 